\title{
SUCCESS FACTORS OF MENTORING AND SUPERVISION BY HOSPITAL SUPERVISORY AGENCY
}

\author{
Faktor Keberhasilan Pembinaan dan Pengawasan \\ oleh Badan Pengawas Rumah Sakit \\ Dea Devita ${ }^{1}$, Septo Pawelas Arso ${ }^{2},{ }^{*}$ Nurhasmadiar Nandini ${ }^{3}$ \\ 1,2,3Faculty of Public Health, Diponegoro University, Indonesia \\ *Correspondence: nurhasmadiar.nandini@live.undip.ac.id
}

\begin{abstract}
Background: Hospital supervisory agency have been established to assist hospitals with maintaining their service quality. Not all provinces have an effective one, however. One agency that is run properly is the Yogyakarta Provincial Hospital Supervisory Agency.

Aim: This study analyzed the success factors of the Yogyakarta Provincial Hospital Supervisory Agency in implementing supervision and mentoring in hospitals in Yogyakarta according to Indonesian Government Regulation No. 49 of 2013.

Methods: This study employed a descriptive-qualitative approach and was conducted in Yogyakarta between January and June 2019. Data were collected using in-depth interviews with participants chosen by a purposive sampling technique.

Results: The Yogyakarta Provincial Hospital Supervisory Agency constructed a mindset that hospitals will benefit from partnering with them. Also, the members of agency had a strong commitment to creating innovative strategies and networking with related stakeholders in spite of low funds from the Yogyakarta Provincial Health Office or the Yogyakarta government.

Conclusion: The success factors of the Yogyakarta Provincial Hospital Supervisory Agency were determined by the high commitment of its members and the well-built cooperation between the agency and the hospitals in Yogyakarta.
\end{abstract}

Keywords: Hospital supervisory board, success factors, mentoring, supervision.

\section{ABSTRAK}

Latar Belakang: Badan Pengawas Rumah Sakit (BPRS) dibentuk untuk mendampingi rumah sakit dalam menjaga kualitas pelayanannya. Namun, hingga saat ini belum semua daerah memiliki BPRS yang berjalan efektif. Salah satu BPRSP yang berjalan dengan baik adalah BPRS Provinsi DI Yogyakarta.

Tujuan: Penelitian ini menganalisis keberhasilan BPRS dalam pelaksanaan fungsi pengawasan dan pembinaan rumah sakit Provinsi Daerah Istimewa Yogyakarta sesuai dengan Peraturan Pemerintah Nomor 49 tahun 2013. Metode: Penelitian ini menggunakan pendekatan deskriptif kualitatif dan dilaksanakan di Yogyakarta dari Januari sampai Juli 2019. Data dikumpulkan dengan wawancara mendalam kepada informan yang dipilih menggunakan purposive sampling.

Hasil: BPRSP DIY berhasil membangun mindset bahwa rumah sakit akan mendapatkan manfaat ketika bekerjasama dengan BPRSP. Selain itu, anggota BPRSP menunjukkan komitmen dan etos kerja yang kuat sehingga dapat menciptakan inovasi strategis dan membangun jaringan dengan berbagai stakeholder terkait tanpa dukungan pendanaan yang cukup dari Dinas Kesehatan DI Yogyakarta maupun pemerintah DI Yogyakarta.

Kesimpulan: Keberhasilan BPRSP DIY didukung tingginya komitmen para anggotanya dan kerjasama yang tersusun dengan baik antara BPRS dan seluruh rumah sakit di Yogyakarta.

Kata kunci: Badan Pengawas Rumah Sakit, faktor keberhasilan, pembinaan, pengawasan.

\section{INTRODUCTION}

Nowadays, there are many regulations that rule the management of hospitals. Hospitals that expect benefits from the regulations may understand and carry their obligations and rights properly. Therefore, as a controller, the government must consider the proper regulations for healthcare service facilities, including hospitals. Government regulations influence improvements in the quality of services provided by public hospitals, therefore, hospitals need to adopt those regulations within hospital management to solve problems (Sari, 2017). Some countries have pathways to optimize the government roles involved in managing public service facilities. This policy is also in line with Law No. 44 of 2009 about hospitals, which states that central government and local government should conduct mentoring and supervision for hospitals. Internal mentoring and supervision is done by a 
hospital supervisory board (Dewan Pengawas Rumah Sakit/DPRS), while the external mentoring and supervision is done by a hospital supervisory agency (Badan Pengawas Rumah Sakit/BPRS).

Although hospital supervisory agencies have an important role in assisting hospitals, not all provinces have one. One of the provinces that does have one is Yogyakarta, with the Yogyakarta Provincial Hospital Supervisory Agency providing external mentoring and monitoring for hospitals. Decree No. 230/KEP/2015 of the Yogyakarta Provincial Governor legitimizes the role of the Yogyakarta Provincial Hospital Supervisory Agency. Chasanah (2016) and Alawiya and Utami (2018) found that it was not fulfilling its responsibilities, however. There were several problems identified, particularly ones related to dispute resolution in hospitals, such as a lack of technical procedures, hospitals' low acceptability, a lack of resources, and funds for operational activities (Chasanah, 2016; Alawiya and Utami, 2018).

Hospital supervisory agencies encourage hospitals to improve the quality of their services, but not all agencies play their roles appropriately. According to the previous studies conducted by Chasanah (2016) and Alawiya and Utami (2018), further studies are needed to evaluate the 2019 performance of the Yogyakarta Provincial Hospital Supervisory Agency to identify any improvements. The present study looks at different discussions that the previous studies did not cover, especially those related to mentoring and supervision regarding dispute resolution in hospitals.

The preliminary study showed that the Yogyakarta Provincial Hospital Supervisory Agency successfully assisted several hospitals in Yogyakarta in 2019. Therefore, this study discusses how the agency successfully carried out its mentoring and supervision responsibilities in terms of human resources and coordination between the agency and the hospitals, and how Yogyakarta Province formulated the policies of supervision for hospitals that led to the agency being established.

\section{METHODS}

This study used a qualitative method with a descriptive approach. The data were collected from in-depth interviews with several participants, including the Head of Yogyakarta Provincial Hospital Supervisory Agency, who carried out the mentoring and supervision, members of the Yogyakarta Provincial Health Office, and staff from the District Public Hospital.

The Head of General Affairs and the Finance Unit in Panembahan Senopati Bantul Hospital was chosen as a representative of a state hospital. Meanwhile, the Head of the Medical Service Unit in Nur Hidayah Hospital was chosen as a representative of a non-state hospital. The other triangulation informant was Yogyakarta Provincial Health Office, that delegated the head of referral service unit.

Participants from a state hospital and a private hospital were chosen so the perspectives of all hospitals in Yogyakarta Province were represented. The Yogyakarta Provincial Hospital
Supervisory Agency is an external organization that has to provide mentoring and supervision at both state and private hospitals. The research variables were regulations and aspects of initiation, input, process and the implementation of the supervision and mentoring conducted by the agency.

\section{RESULTS AND DISCUSSION}

Public policy is a guide to action and policy implementation that involves interpreting the goals and objectives of a policy and turning them into actions (Khan, 2016). This study analyzed the implementation regarding Yogyakarta Provincial Hospital Supervisory Agency in Yogyakarta. The implementation of a policy requires clarification of the goals, missions, and objectives; detailed planning; appropriate job assignments; effective monitoring and evaluation; and comprehensive and efficient operating procedures and techniques. These aspects assist the implementers with defining the scope of their responsibilities according to the policy objectives to achieve their goals (Khan and Khandaker, 2016). The initiative to establish the Yogyakarta Provincial Hospital Supervisory Agency was one of the policies implemented.

"There were a lot of conflicts between
hospital and community. So, we need
an external organization to solve the
problems and become a mediator.
Therefore, Yogyakarta Provincial
Health Office initiated the building of the
Yogyakarta Provincial Hospital
Supervisory Agency." (Main participant)
"When Yogyakarta Provincial Hospital
Supervisory Agency visited our
hospital, we could understand our
strengths and shortcomings."
(Participant 2)

The Yogyakarta Provincial Hospital Supervisory Agency aims to solve problems between communities and hospitals and help the latter assess and evaluate their performance. External evaluators tend to be more neutral than internal evaluators because they have no relationship with the hospitals. Indeed, Araújo et al. (2019) mentioned that internal evaluators usually provide more favorable results than external evaluators. There were several evaluation models designed to evaluate hospital performance, however, these might have been implemented differently in each hospital based on the hospitals' various characteristics (Bahadori et al., 2016).

The difficulties in determining hospital evaluation models occurred due to the lack of systematic views by experts, the lack of attention to some stages of the evaluation process due to personal preferences, a lack of manpower, etc. (Bahadori et al., 2016). These causes could be 
prevented by establishing an external evaluator team, such as BPRS.

The results showed there were regulations that the Yogyakarta Provincial Hospital Supervisory Agency referred to when providing mentoring and supervision. For example, there were central regulations, such as Law No. 44 of 2009 regarding hospitals; Government Regulation No. 49 of 2013 regarding the Hospital Supervisory Board; Indonesian Ministry of Health Regulation No. 17 of 2014 on the membership, assignation, and discontinuance of members of the Indonesia hospital supervisory board; Indonesian Ministry of Health Regulation No. 88 of 2015 on guidelines for supervision and reporting and information systems for mentoring and supervision implemented by the hospital supervisory board; and other regulations related to hospital mentoring and supervision. The problem is the unavailability of strong regulations at a regional level in Yogyakarta Province as the available regional regulation is merely Governor Decree No. 175/KEP/2018.

The Yogyakarta Provincial Hospital Supervisory Agency was initially established by the Yogyakarta Provincial Health Office within a short period of time. The participants stated that the agency was established in 2015 before the central government's regulation was officially published. The quick establishment of the agency occurred because the hospitals were actively looking for information about mentoring and supervision. Therefore, once they identified the functions of mentoring and supervision, they were motivated to partner with the agency.

The hospitals also gained relative advantages after being partnered with the Yogyakarta Provincial Hospital Supervisory Agency. For example, they continued to improve the quality of their services, received comprehensive guidance, and gained an understanding of patient rights and obligations. Moreover, the agency could help with conflict resolution within the hospitals.

In the beginning, the disposition of the Yogyakarta Hospital Supervisory Agency's roles was adjusted to the standard of the Central Hospital Supervisory Agency, as the Indonesian Ministry of Health Regulation No. 88 of 2015 mentions. However, the agency's roles would still be conditional by considering the conditions of hospital management in coordination with the hospitals and the provincial health office in Yogyakarta Province. Such policy is more applicable for the hospital.

The hospitals had little funding for the provision of healthcare services. However, once the Yogyakarta Province Hospital Supervisory Agency had conducted its mentoring and supervision, they found a creative strategy for adding funds. Thus, they streamlined the workflow to conduct services at the hospitals to save more money.

Other participants said that even though the employees of the Yogyakarta Provincial Hospital Supervisory Agency did not get paid in the first year, they never felt discouraged about visiting all the hospitals. This showed that the employees supported the implementation of the policies in the hospitals. The sustainability of policy implementation, such as mentoring and supervision, depends on individual support.

From a human resources perspective, there is still a minimal number of employees at the Yogyakarta Provincial Hospital Supervisory Agency, although there are six employees conducting mentoring and supervision. The Indonesian Government Regulation No. 49 of 2013 concerning Hospital Supervisory Agency explains the agency should just assign maximum of five employees. One of the six employees is a contract worker for the Health Service Department of Yogyakarta Provincial Health Office, however. The exceeding number employees recruited aims to prevent insufficient human resources during mentoring and supervision, therefore, it was expected to optimize the implementation of services.

"There was no specific job distribution. We usually sit together and discuss the issues we need to solve. We never questioned who solves the problem. The important thing is that we are able to solve the problem." (Main participant)

"If there is a problem or issue, Yogyakarta Provincial Hospital Supervisory Agency will discuss it together, analyze the problem, and ask the related party to reach an agreement." (Participant 1)

Even though the Yogyakarta Provincial Hospital Supervisory Agency only has a small team, they have showed great and effective teamwork when solving problems in Yogyakarta. Teamwork refers to interpersonal interactions and collaboration among team members within an organization. Effective teamwork is characterized by good communication and collaboration among team members as they work together to achieve common goals (Hwang, 2018).

Despite the virtuous teamwork, however, the Yogyakarta Provincial Hospital Supervisory Agency has not provided training regarding hospital mentoring and supervision for their employees as mediators, even though it is needed. Training can enhance the learning skills of the employees and improve work efficiency and organizational performance (Mohan and Gomathi, 2015; Jyoti and Rani, 2017). Therefore, the employees require proper training to become certified mediators.

The primary participant was a representative of the ombudsman, a supervisory public service institution incorporated with the Yogyakarta Provincial Hospital Supervisory Agency, and they stated that a training certificate was very important for the mediators. Once a conflict is mediated by a 
certified mediator, the memorandum of understanding made by the certified mediator can be registered with the court and binds the parties to execute the agreement that need to be obeyed.

Meanwhile, the budget was allocated by the local government budget according to the regulation regarding funding sources for the Yogyakarta Provincial Hospital Supervisory Agency. A problem that arose was the insufficiency of funds and the flow of incoming funds.

\section{"The funds are not enough, but we try to make it enough. For us, funds are not an obstacle which makes our program cancelled. We have various strategies to make sure our program runs with the minimum funds." (Main participant)}

Until now, the Yogyakarta Provincial Hospital Supervisory Agency perceived the budget as being too small to conduct the mentoring and supervision program. In other words, sufficiency of budget will affect the success of program implementation. To overcome the issue of insufficient funds, the employees of the agency suggested networking to help them implement mentoring and supervision for the hospitals.

Networking between hospitals and other related institutions has become increasingly popular in the health sector. This is because hospitals need to have a better understanding of the challenges and issues in healthcare and need to find solutions and share their best practices (Loss et al., 2018). Networking helped the Yogyakarta Provincial Hospital Supervisory Agency socialize new issues in hospital healthcare services. This strategy can be a new way and sources for years to come. Hospital networking provides many benefits for hospitals in terms of financing, information sharing, and risk distribution (Reames, Anaya, and Are, 2019). Therefore, hospital networking in Yogyakarta has greatly contributed to the supervision and guidance conducted by the agency.

Despite the sufficiency of funds, the flow of funding allocation was still complicated because it was given to the Yogyakarta Provincial Health Office first, then to the health service department before being transferred to the Yogyakarta Provincial Hospital Supervisory Agency. Therefore, the agency is not the first in line to receive the funds.

Also, the infrastructure to support hospital mentoring and supervision is available but inadequate, and it is not feasible as it tends to be shared with the health service department in the Yogyakarta Provincial Health Office. When executing its mentoring and supervision, the Yogyakarta Provincial Hospital Supervisory Agency has standard operating procedures (SOPs). The SOPs combine the central regulations and Yogyakarta's specific conditions and focus on five aspects of hospital assessment shorten from seven aspects originally.

\begin{abstract}
"We made a standard instrument according to our team consensus. It was developed based on the regulation, and we adjusted the instrument to the hospitals' condition and needs." (Main participant)
\end{abstract}

This instrument is very helpful for hospital mentoring and supervision in Yogyakarta as it simplifies the assessment process and allows similar data to be obtained from all hospitals. Although each employee of the Yogyakarta Provincial Hospital Supervisory Agency had their own tasks in different schedules, the SOPs standardize the results no matter who does the evaluation. This showed that the agency has done well when implementing its hospital mentoring and supervision as it has a clear and standardized reference that minimizes the risk of bias.

Before implementing a service, the hospitals receive suggestions from the planning process followed by the Yogyakarta Provincial Hospital Supervisory Agency. The agency plans strategies for budgeted activities and non-budgeted activities, such as networking. The system planning is done every Monday when the employees of the agency are gathered together. A continuously fundamental process of decision-making is done systematically.

The planning stage also means the Yogyakarta Provincial Hospital Supervisory Agency has visionary and comprehensive ways of thinking because the planning includes the analysis of available resources, the integration of government politicians' support, and community participation as a way of achieving the organization's targets.

Another finding was that the Yogyakarta Provincial Hospital Supervisory Agency have not devided obligation in the bureaucracy structure. They do not consider organizational structure, where a chairman has been assigned. All employees have the same level of problem solving and decision-making done with a mutual agreement. This kind of bureaucratic structure can result in difficulties for determining the core team of the organization when a conflict occurs between members, however. As a result, the agency did not think about the conflict resolution which can happen at any time.

This issue is a result of the weak regulation regarding hospital supervisory agencies. For example, the Indonesian Ministry of Health Regulation No. 17 of 2014 regarding the membership, assignation, and discontinuance of members of Indonesia's hospital supervisory agencies and Government Regulation No. 49 of 2013 regarding hospital supervisory agencies do not mention detailed positions and job distribution to all employees assigned to hospital mentoring and supervision.

It is noticeable that hospital mentoring and supervision is a result of coordination between the Yogyakarta Provincial Hospital Supervisory Agency, 
the health service department of the Yogyakarta Provincial Health Office, the hospitals, and the stakeholders. The agency conducts mentoring and supervision by direct visitation and invitation to all the hospitals in Yogyakarta and by visiting the Yogyakarta Provincial Health Office and discussing the issues in the hospitals.

Before visiting a hospital, the Yogyakarta Provincial Hospital Supervisory Agency sends a letter with the visitation agenda to the hospital and then forms different teams that all include hospital staff members to survey all hospital areas. After the visit, the agency presents all its findings (both positive and negative) and gives recommendations. After implementing hospital mentoring and supervision, the agency writes a report about the activities and submits it to the Yogyakarta Provincial Health Office. The Yogyakarta Provincial Health Office then submits the report to the local government and the central provincial hospital supervisory agency.

To shorten the bureaucratic process, a copy of the report is also sent directly to the central provincial hospital supervisory agency by the Yogyakarta Provincial Hospital Supervisory Agency. These procedures are in line with the Indonesian Ministry of Health Regulation No. 88 of 2015 regarding guidelines for supervision and reporting and information systems for hospital mentoring and supervision by hospital supervisory agencies.

The Yogyakarta Provincial Hospital Supervisory Agency always promotes itself as a partner and colleague of the hospitals, allowing for a more open and viable discussion that helps the hospitals improve.

"We already submitted our
recommendations to the hospitals in
late 2018 and are still waiting for the
response from the Yogyakarta
Provincial Health Office. However, we
also gave recommendations directly to
the hospitals during our visit or
discussion." (Main participant)

"There were several recommendations given to our hospital in the form of a report a few days after the hospital visit. For simple recommendations which do not need a lot of funds, we execute them as soon as possible. However, for recommendations that need a lot of funds, we usually adjust them first with the hospital budget." (Participant 2)

The follow-up reports were submitted at the end of 2018, however, the Yogyakarta Provincial Hospital Supervisory Agency just gave the hospitals personal recommendations that have been applied.

The process of monitoring and evaluation is still insufficient. The Yogyakarta Provincial Hospital Supervisory Agency have not conducted structured, planned, and scheduled mentoring and evaluation until now. Research by Kennedy, Anastos, and Genau (2019) showed that regular monitoring and evaluation, such as regular feedback sessions with hospital staff, are an important part of healthcare management and the quality of service strategies. Improving the quality of services requires a comprehensive approach. The agency have already implemented this concept using various approaches, but this concept was not scheduled or regularly conducted as a quality management team could not be formed due to insufficient hospital human resources.

The monitoring and evaluation conducted by the Yogyakarta Provincial Hospital Supervisory Agency is merely an individual appraisal of the implemented program, the unimplemented program, and the future program. The agenda needs more detailed components that comprise the inputs (planning, organizing, and action) and outputs of the activities.

It is important to improve the quality of hospital monitoring. Research by Widyacahya and Wulandari (2018) showed that monitoring influences a team's performance regarding hospital management. Capable staff members in the team can optimize the monitoring and evaluation and lead to better hospital performance (Widyacahya and Wulandari, 2018).

The communication between the employees at the Yogyakarta Provincial Hospital Supervisory Agency is effective as they communicate either online or face-to-face every Monday. They utilize online messaging application optimally where they can do their task and make a quick decision if something urgent happens. Communication has a positive impact on work performance and allows organizations to function optimally and creatively (Shoaib et al., 2017).

In contrast, the communication between the Yogyakarta Provincial Hospital Supervisory Agency and the related parties was considered ineffective and suboptimal. As one participant said, communication between the agency and the hospitals was only done via email and letter before a one-year hospital visitation was conducted. Few number of visits occur because there are many options of hospitals in Yogyakarta. The agency's team only consists of six people, making it was difficult for them to maintain intense and routine communication between hospitals and the agency.

The policy brief of hospital mentoring and supervision has been delivered well by the Yogyakarta Provincial Hospital Supervisory Agency. Information about the agency and an integrated survey was well-disseminated to all the hospitals and the community.

"Mentoring and supervision by the Yogyakarta Provincial Hospital Supervisory Agency are implemented in various ways. Sometimes we visit the hospital, but other times we invite 
hospitals' representatives to discuss current issues related to hospital." (Main participant)

\begin{abstract}
"Sometimes the Yogyakarta Provincial Hospital Supervisory Agency comes and visits our hospital. They are divided into teams. One team will assess our hospital management, and the other team accompanied by us will go around the hospital." (Participant 2)
\end{abstract}

The implementation of the policy is unique as it is done in various ways, such as by direct surveys of the hospitals, invitations for the hospitals to discuss the policy of hospital mentoring and supervision, and by radio broadcasting in the form of a talk show with questions and answers. During the implementation of the campaign strategies, the hospitals could use the funds effectively and build a stronger image within the community.

The output variable showed that most of the targets have been reached. Due to the unstructured, unplanned, and unscheduled mentoring and evaluation, the attainment of the targets can be described from the output, e.g. successfully visiting all hospitals in Yogyakarta Province. Other targets, such as the progress of service improvement, patient empowerment, and the community's rights to healthcare services, are in progress, however. As the Yogyakarta Provincial Hospital Supervisory Agency did not provide detailed outputs, the indicators of success and standard assessment remain unknown. Whereas, those two indicators are particularly important in monitoring and evaluation.

Another problem is not being able to resolve the community's complaints because there is no governor regulation and no infrastructure to perform the task. Research by Kasnakoglu, Yilmaz, and Varnali (2016) showed that effective management of customer complaints positively impacts customer satisfaction and needs to be improved. Poor complaint management may result in difficulty identifying areas that need improvement (Kasnakoglu, Yilmaz and Varnali, 2016).

As a result, the Yogyakarta Provincial Hospital Supervisory Agency cannot fully implement the appropriate procedures for hospital mentoring and supervision as mandated in the Government Regulation No. 49 of 2013. Although this is an obstacle, the hospitals have still benefitted from the mentoring and supervision. For example, the hospitals are more aware of their strengths and weaknesses and more enthusiastic about improving their performance and preventing potential harm to patients. They were also given great guidance, reminders, and supervision by the agency, which is considered to be their partner. The agency also recommended some viable solutions that were easy to implement and resulted in noticeable improvement.

\section{CONCLUSION}

The success factors of the Yogyakarta Provincial Hospital Supervisory Agency are determined by the high commitment of the employees and good cooperation between the agency and the hospitals in Yogyakarta. This good cooperation is the result of the hospitals' acceptance of the mentoring and supervision.

\section{CONFLICT OF INTEREST}

The authors state that there is no conflict of interest in this article.

\section{REFERENCES}

Alawiya, N. and Utami, N. A. T. (2018) 'Implementasi Penyelesaian Sengketa Rumah Sakit Melalui Badan Pengawas Rumah Sakit Provinsi (Studi di BPRSP Provinsi Daerah Istimewa Yogyakarta)', in Pengembangan Sumber Daya Pedesaan dan Kearifan Lokal Berkelanjutan VIII. Purwokerto: Universitas Jenderal Soedirman, pp. 341-348. Available at:

http://jurnal.Ippm.unsoed.ac.id/ojs/index.php/ Prosiding/article/viewFile/654/592.

Araújo, R. G. et al. (2019) 'External evaluation and self-monitoring of the Baby-friendly Hospital Initiative's maternity hospitals in Brazil', International Breastfeeding Journal, 14(1), pp. 1-9. doi: 10.1186/s13006-018-0195-4.

Bahadori, M. et al. (2016) 'The Evaluation of Hospital Performance in Iran: A Systematic Review Article', Iranian Journal of Public Health, 45(7), pp. 855-866. Available at: https://www.ncbi.nlm.nih.gov/pmc/articles/PM C4980339/.

Bravi, F. et al. (2013) 'Hospital network performance: A survey of hospital stakeholders' perspectives', Health Policy, 109(2), pp. 150157. doi: 10.1016/j.healthpol.2012.11.003.

Chasanah, U. (2016) Kesiapan Badan Pengawas Rumah Sakit Provinsi Daerah Istimewa Yogyakarta Dalam Pelaksanaan Tugas Menyelesaikan Sengketa Melalui Mediasi. Master Thesis. Universitas Katolik Soegijapranata.

Hwang, M. I. (2018) 'Relationship between teamwork and team performance: Experiences from an ERPsim competition', Journal of Information Systems Education, 29(3), pp. 157-168. Available http://www.jise.org/Volume29/n3/JISEv29n3p 157.pdf.

Johansson, F. (2004) The Medici Effect: Breakthrough Insights at the Intersection of Ideas, Concepts, and Cultures. United States: Harvard Business Review Press.

Jyoti, J. and Rani, A. (2017) 'High performance work system and organisational performance: role of knowledge management', Personnel Review, 46(8), pp. 1770-1795. doi: 10.1108/PR-10-2015-0262.

Kennedy, D. M., Anastos, C. T. and Genau, M. C. (2019) 'Improving healthcare service quality 
through performance management', Leadership in Health Services, 32(3), pp. 477-492. doi: 10.1108/LHS-02-2019-0006.

Khan, A. R. (2016) 'Policy Implementation: Some Aspects and Issues', Journal of Community Positive Practices, 16(3), pp. 3-12. doi: $10.2307 / 975319$.

Khan, A. R. and Khandaker, S. (2016) 'A critical insight into policy implementation and implementation performance', Public Policy and Administration, 15(4), pp. 538-548. doi: 10.13165/VPA-16-15-4-02.

Loss, J. et al. (2018) 'Social capital in a regional interhospital network among trauma centers (trauma network): results of a qualitative study in Germany', BMC health services research, 18(137), pp. 1-14. Available at: https://link.springer.com/article/10.1186/s129 13-018-2918-z.

Mohan, K. and Gomathi, S. (2015) 'The Effects of Job Rotation Practices on Employee Development: An Empirical Study on Nurses in the Hospitals of Vellore District', Mediterranean Journal of Social Sciences, 6(1), pp. 209-215. doi: 10.5901/mjss.2015.v6n1p209.

Reames, B. N., Anaya, D. A. and Are, C. (2019) 'Hospital Regional Network Formation and "Brand Sharing": Appearances May Be Deceiving"', Annals of Surgical Oncology, 26(3), pp. 711-713. doi: 10.1245/s10434018-07129-2.

Sari, W. I. R. (2017) 'The role of regulations on administrative and practices in improving quality of services in public organizations', Cogent Business and Management, 4(1396952), pp. 1-16. doi: $10.1080 / 23311975.2017 .1396952$.

Shoaib, R. et al. (2017) 'The Relationship Between HRM Practice, Workplace Communication and Job Performance of Service Industries Employees in Vehari, Pakistan', International Journal of Information, Business and Management, 9(2), pp. 122-140.

Symond, D. (2007) 'Kajian Perencanaan Dan Penganggaran Kesehatan Di Dinas Kesehatan Kota Padang Tahun 2006', Jurnal Kesehatan Masyarakat, 2(1), pp. 116-123.

Taslimi, M. S. and Zayandeh, M. (2013) 'Challenges of Hospital Performance Assessment System Development: Literature Review', HAKIM Health Systems Research Journal, 16(1), pp. 35-41.

Widyacahya, F. and Wulandari, R. D. (2018) 'Pengaruh Pengawasan dan Kondisi Kerja terhadap Keterlibatan Kerja Karyawan Rumah Sakit Mata Undaan Surabaya', Jurnal Administrasi Kesehatan Indonesia, 6(1), pp. 21-26. doi: 10.20473/jaki.v6i1.2018.21-26. 